\title{
Effect of Process Variables on the Quality Attributes of Briquettes from Wheat, Oat, Canola and Barley
}

\section{ASABE Annual International Meeting}

Jaya Shankar Tumuluru

L. G. Tabil

$Y$. Song

K. L. Iroba

V. Meda

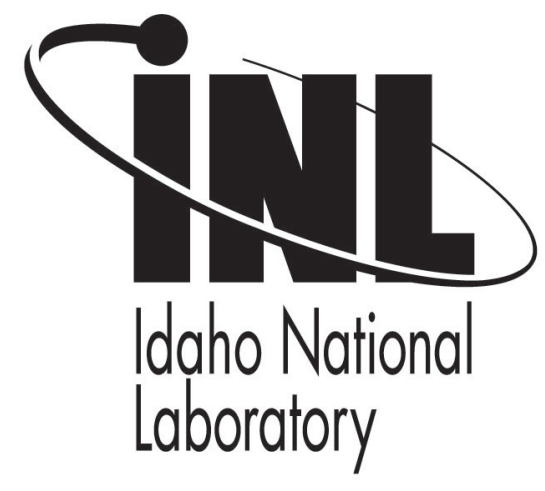

\section{August 2011}

This is a preprint of a paper intended for publication in a journal or proceedings. Since changes may be made before publication, this preprint should not be cited or reproduced without permission of the author. This document was prepared as an account of work sponsored by an agency of the United States Government. Neither the United States Government nor any agency thereof, or any of their employees, makes any warranty, expressed or implied, or assumes any legal liability or responsibility for any third party's use, or the results of such use, of any information, apparatus, product or process disclosed in this report, or represents that its use by such third party would not infringe privately owned rights. The views expressed in this paper are not necessarily those of the United States Government or the sponsoring agency. 


\title{
Effect of Process Variables on the Quality Attributes of Briquettes from Wheat, Oat, Canola and Barley
}

\author{
Jaya Shankar Tumuluru ${ }^{1 *}$, L. G. Tabil ${ }^{2}$, Y. Song ${ }^{3}$, K. L. Iroba ${ }^{2}$ and V. Meda ${ }^{2}$ \\ ${ }^{1 *}$ Biofuels and Renewable Energies Technologies, Idaho National Laboratory, 2351 North Blvd, Idaho \\ Falls, Idaho, 83415-2025. \\ ${ }^{2}$ Department of Agricultural \& Bioresource Engineering, University of Saskatchewan, 57 Campus \\ Drive, Saskatoon, SK CANADA S7N 5A9. kli931@mail.usask.ca \\ ${ }^{3}$ College of Engineering, Shenyang Agricultural University, Shenyang, China
}

\author{
Written for presentation at the \\ 2011 ASABE Annual International Meeting \\ Sponsored by ASABE \\ Gault House \\ Louisville, Kentucky \\ August $7-10,2011$
}

(Part of this paper was presented in CIGR meeting, 2010)

\begin{abstract}
Biomass is a renewable energy source and environmentally friendly substitute for fossil fuels such as coal and petroleum products. Major limitation of biomass for successful energy application is its low bulk density, which makes it very difficult and costly to transport and handle. To overcome this limitation, biomass has to be densified. The commonly used technologies for densification of biomass are pelletization and briquetting. Briquetting offers many advantages at it can densify larger particles sizes of biomass at higher moisture contents. Briquetting is influenced by a number of feedstock and process variables such as moisture content, particle size distribution, and some operating variables such as temperature and densification pressure. In the present study, experiments were designed and conducted based on Box-Behnken design to produce briquettes using barley, wheat, canola and barley straws. A laboratory scale hydraulic briquette press was used for the present study. The experimental process variables and their levels used in the present study were pressure levels $(7.5,10,12.5 \mathrm{MPa})$, three levels of temperature $\left(90,110,130^{\circ} \mathrm{C}\right)$, at three moisture content levels (9, 12, 15\% w.b.), and three levels of particle size (19.1, 25.04, $31.75 \mathrm{~mm})$. The quality variables studied includes moisture content, initial density and final briquette density after two weeks of storage, size distribution index and durability. The raw biomass was initially chopped and size reduced using a hammer mill. The ground biomass was conditioned at different moisture contents and was further densified using laboratory hydraulic press. For each treatment combination, ten briquettes were manufactured at a residence time of about $30 \mathrm{~s}$ after compression pressure setpoint was achieved. After compression, the initial dimensions and the final dimensions after 2 weeks of storage in controlled environment of all the samples were measured. Durability,
\end{abstract}


dimensional stability, and moisture content tests were conducted after two weeks of storage of the briquettes produced. Initial results indicated that moisture content played a significant role on briquettes durability, stability, and density. Low moisture content of the straws (7-12\%) gave more durable briquettes. Briquette density increased with increasing pressure depending on the moisture content value. The axial expansion was more significant than the lateral expansion, which in some cases tended to be nill depending on the material and operating variables. Further data analysis is in progress in order to understand the significance of the process variables based on ANOVA. Regression models were developed to predict the changes in quality of briquettes with respect of the process variables under study.

Key Words: Agricultural straws, densification, briquettes, density, durability, dimensional stability, ANOVA and regression equations

Note: This work was done by the corresponding author while working as a Research Associate in the Department of Agricultural and Bioresource Engineering, University of Saskatchewan, Saskatoon, Canada. 


\section{Introduction}

The world is currently facing challenges to reduce dependence on fossil fuels and to achieve a sustainable renewable energy supply. Renewable energies represent a diversity of energy sources that can help maintain the equilibrium of different ecosystems. Among the various sources of renewable energy, biomass is increasingly used as it is considered carbon neutral, since the carbon dioxide released is already part of the carbon cycle (Arias et al., 2008). Increasing the utilization of biomass for energy can help reduce the negative $\mathrm{CO}_{2}$ impact on the environment and help meet the targets established in the Kyoto Protocol (UN, 1998). Energy from biomass can be produced from different processes like thermochemical (combustion, gasification, and pyrolysis), biological (anaerobic digestion and fermentation), or chemical (esterification), in which direct combustion can provide a direct near-term energy solution (Arias et al., 2008).

Agricultural biomass residues are sources of renewable and sustainable biofuels which can contribute significantly to mitigate the effect of greenhouse gas (GHG) emissions if properly managed and utilized (Sokhansanj et al. 2006; Hoekman 2009; Kaliyan and Morey 2009). Agricultural residues constitute one of the important biomass feedstocks in Canada, due to its vast agricultural base. According to Saskatchewan Ministry of Agriculture (2008), Saskatchewan alone produced 12.44 million t of wheat, 5.63 million t of canola, 4.59 million $t$ of barley, and 2.3 million $t$ of oat in 2008. This abundance, inexpensive and readily available biomass source indicates that Canada can play a very significant role in the development of environmentally benign bioenergy sector.

However, biomass in its natural form is bulky, loose, and dispersed. Biomass feedstocks are often collected in baled forms; hence they are difficult to handle during utilization and do not present economical and efficient transportation and storage characteristics due to low bulk density of bales (40-200 kg/m ${ }^{3}$ ) and large volume requirements (Tabil 1996; Sokhansanj et al. 2005; Sokhansanj et al. 2006; Mani et al. 2006a; Adapa et al. 2009a). Despite the difficulties of handling, storage, and transportation, the direct combustion of loose biomass in conventional grates is associated with very low thermal efficiency. The conversion efficiencies are as low as $40 \%$ with widespread of air pollution in the form of very fine particulate matters (Grover and Mishra 1996; Granada et al. 2002; Kaliyan and Morey 2009).

In order to mitigate the above mentioned shortcomings of agricultural biomass residues, and to enhance flowability and reduce material waste, they must be processed and handled in a more efficient manner. Biomass densification is defined as the compression or compaction of biomass to eliminate inter- or intra particle voids. Densification of biomass feedstocks into durable compacts increases the efficiency of handling and can significantly increase the bulk density to about $500-800 \mathrm{~kg} / \mathrm{m}^{3}$ (Mani et al. 2003; Obernberger and Thek 2004). Biomass straws densified into pellets increases in particle density to about $823-1011 \mathrm{~kg} / \mathrm{m}^{3}$ (Adapa et al. 2009a). Due to the uniformity in shape and sizes, densified products can be handled easily using the standard handling and storage equipment, and can be easily adopted in direct-combustion or co-firing with coal, gasification, pyrolysis, and in other biomass-based conversions (Kaliyan and Morey 2009).

Conventional processes for biomass densification can be classified into baling, pelletization, extrusion, and briquetting, which are carried out using a bailer, pelletizer, screw press, piston or a roller press. Pelletization and briquetting are the most common processes used for biomass densification for solid fuel applications. These high-pressure compaction technologies, also called "binderless" technologies, are usually carried out using either a screw press or a piston press (Sokhansanj et al. 2005). In a screw press, the biomass is extruded continuously through 
a heated, tapered die. The briquette quality and production process of a screw press are superior to piston press technology. However, comparing wear of parts in a piston press, like a ram and die, to wear observed in a screw press shows that the screw press parts require more maintenance. The central hole incorporated into the densified logs produced by a screw press helps achieve uniform and efficient combustion, and the resulting logs can be carbonized more quickly due to better heat transfer.

Many researchers have worked on the densification of herbaceous and woody biomass using pellet mills and screw/piston presses. For instance, Tabil and Sokhansanj (1996) worked on understanding the compression characteristics of alfalfa pellets. Ndiema et al. (2002) examined the influence of die pressure on relaxation characteristics of briquetted biomass. Adapa et al. (2003) studied pelleting fractionated alfalfa products. Li and Liu (2000) investigated highpressure densification of wood residues to form an upgraded fuel. Mani et al. (2006a) researched the compaction characteristics of lignocellulosic biomass using an Instron, and Tumuluru et al. (2010) studied the effect of pelleting process variables on the quality attributes of a wheat distiller's dried grains with solubles.

The densification process is affected by physical properties and chemical composition of the biomass, which includes compounds like cellulose, hemicelluloses, protein, starch, lignin, crude fiber, fat, and ash. During compression at high temperatures, the protein and starch plasticizes and acts as a binder, which assists in increasing the strength of the pellet (Briggs et al. 1999). Starch present in the biomass acts as binder during densification. During densification of starchrich biomass using an extrusion process like pelleting, the presence of heat and moisture gelatinizes the starch and results in better binding (Wood 1987; Thomas et al. 1998). High temperature and pressure, which are normally encountered during the densification process, results in softening of the lignin and improves the binding ability of the biomass. Low thermosetting properties and a low melting point $\left(140^{\circ} \mathrm{C}\right)$ help lignin take an active part in the binding phenomena (van Dam et al. 2004). Protein, starch, and lignin present in biomass takes an active part during pelleting of alfalfa, wheat, and barley grinds (Tabil and Sokhansanj 1996). Application of high compression pressures during biomass densification can result in crushing the biomass particles, thus opening up the cell structure and exposing the protein and pectin that act as natural binders (Bilanski and Graham 1984). The major difference between biomass and other materials, like ceramic powders and pharmaceutical powders, is the presence of natural binding materials (Kaliyan and Morey 2006). The presence of components like bark, stems, leaves, etc., in the biomass further complicates understanding of the compaction behavior. Recently, Kaliyan and Morey (2010) used scanning electron microscope (SEM) studies for understanding the solid-type bridges formed during briquetting and pelleting of corn stover and switchgrass. More studies at a micro level using techniques like SEM and TEM will be useful in understanding the interaction of feedstock and process variables on the quality attributes of densified biomass.

Moisture content is considered as one of the important feedstock variable which plays a significant role in the physical properties of compacts and enhances it binding characteristics to produce a quality product with high density. Several studies showed that strength, stability, and durability of densified biomass products increased with increasing moisture content until an optimum is reached. Low moisture chopped corn stover (5-10\% w.b.) resulted in denser, more stable, and durable pellets than high moisture stover (15\% w.b.) (Mani et al. 2006a). Particle and bulk densities of biomass compacts decreased with increasing moisture content. This decrease is due to the expansion of the compact volume, caused by increase in moisture content (Colley et al. 2006). Water acts as a binding agent by strengthening the bonding in the material (Kaliyan and Morey 2009). Water helps to develop van der Waals' forces by increasing 
the area of contact between particles (Grover and Mishra 1996). At high moisture content, water acts as a lubricant and reduces the binding property of the material even at high pressures, this leads to poor quality and low pellet density (Mani et al. 2006b). In the same manner moisture content has effect on the porosity of pellets. Colley et al. 2006 demonstrated that the porosity of pellets ranged from 51.61 to $62.62 \%$ with varying moisture contents. These researchers obtained a minimum porosity of $51.61 \%$ at $8.62 \%$ moisture content.

Particle size is another important feedstock variable which influences the quality of densified pellets and briquettes. Studies have demonstrated that agricultural biomass residues are usually ground to reduced particle sizes so as to increase the surface area, to produce denser pellets and enhance the pelleting capacity (Tabil 1996; Sokhansanj et al. 2005). Particle size reduction is very important in densification of biomass. In general, the finer the grind, the higher the dimensional stability and durability of the biomass compacts. Fine particles usually adsorb more moisture than large particles; hence, they undergo a higher degree of conditioning. Also, large/coarse ground materials tend to produce less quality compacts because they may create natural fissure points that cause cracks and fractures (cited by Tabil 1996; cited by Kaliyan and Morey 2009). Mani et al. (2004a) studied the grinding performance and physical properties of wheat and barley straws, corn stover and switchgrass. They concluded that the energy consumption for grinding increases as the particle size of the ground biomass becomes finer. Kaliyan and Morey (2006) investigated the effects of particles size $(0.56$ to $0.8 \mathrm{~mm})$ on the densification characteristics of corn stover and switchgrass. They concluded that decreasing the geometric mean particle size of ground corn stover from 0.8 to $0.66 \mathrm{~mm}$ increased the density of briquettes by 5 to $10 \%$, durability by 50 to $58 \%$ at $100 \mathrm{MPa}$ pressure, and by 62 to $75 \%$ at 150 $\mathrm{MPa}$ at a moisture content of $10 \%$. They also reported that such decreased in the particle size increased the specific energy consumption from 0.8 to $1.3 \mathrm{MJ} / \mathrm{t}$.

The stability, durability, strength of biomass compact, as well as the power requirement for densification significantly depends on the applied temperature. Heat is added to the densification process by means of preheating of the feed materials or by the use of heated die apart from the frictional heat generated resulting from compression ((Adapa et al. 2009b). Mani et al. (2003) cited that the higher the temperature the lower the force needed to provide a given degree of compaction. Lignin plays a role in the bonding of particles during densification. When biomass is subjected to heat (temperature above $140^{\circ} \mathrm{C}$ ) and high pressure, lignin tends to become soft, melts and exhibits thermosetting binder resin properties (Van Dam et al. 2004). However, densification temperature should not be more than $300^{\circ} \mathrm{C}$ which is the decomposition temperature of biomass (Grover and Mishra 1996).

Biomass density and durability increases as the applied pressure increases depending on the moisture content of the biomass. Densification of biomass under high pressure creates mechanical interlocking and increases adhesion between the particles, generating the intermolecular bonds within the contact area (Grover and Mishra 1996). Application of pressure enhances different binding mechanisms. The natural binding components such as starch, protein, lignin, and pectin in biomass materials are squeezed out of the particles under pressure, thereby contributing to inter-particle bonding (Kaliyan and Morey 2009). Mani et al. (2006a) reported that applied pressure had the highest effect on the total energy consumption.

Controlling the feedstock and process variables can lead to production of high quality and durable compacts. To explore the feasibility of densification of agricultural straws for solid fuel biofuel application, agricultural biomass residues like barley, canola, oats, and wheat straw were densified into briquettes. The feedstock variables studied were moisture content and particle size and process variables are temperature and application pressure. The densified briquettes were evaluated for the physical quality attributes like initial bulk density, final bulk density after two weeks of storage, moisture content, dimensional stability, size distribution index and 
durability index. The combination of process and feedstock vaaribles is the driving force behind the production of dimensionally stable compacts with high density, durability, and at minimum cost. Understanding the effect of process variables and their effect is critical for understanding the briquetting process.

In general understanding the effect of process variables on process and product development is carried out using response surface methodology (RSM). RSM which is a combination of mathematical and statistical techniques is commonly used for process development (Khuri and Cornell, 1987). RSM has been widely used for developing quadratic models to describe the extrusion process. Many researchers like Frazier et al. (1983); Shankar and Bandyopadhyay (2004 \& 2005) and Shankar et al. (2010) used response surface methodology to understand the effect of process variables on the product characteristics.

\section{Objectives}

It has been observed by many researchers that proved that the briquetting process variables like moisture content, particle size, temperature and retention time influence the quality attributes of the briquettes made from agricultural straws. The objective of the present study is understand the effect of the briquetting process like particle size in the range of 19.1-31.75 mm, pressure in the range of $7.5-12.5 \mathrm{MPa}$, moisture in the range of $9-15 \%$ and temperature in the range of $90-130{ }^{\circ} \mathrm{C}$. Experiments were conducted based on Box-Behnken design for four different agricultural straws like wheat, barley, oat and canola at three levels. ANOVA analysis and response surface models were developed to predict the changes in the quality attributes of the briquettes produced.

\section{MATERIALS AND METHODS}

Four different types of agricultural biomass residues (barley, canola, oat, and wheat straw) were collected and used for the experiments. The straw samples were gathered during the summer of 2009 and chopped into three different particle size distributions using screen size openings of $19.1,25.04$, and $31.75 \mathrm{~mm}$. Each of these three samples was conditioned to moisture content of 9, 12, and $15 \%$ w.b. based on American Society of Agricultural and Biological Engineers (ASABE) Standard S358.2 (ASABE 2006). The samples were subsequently stored in Ziploc bags at a controlled environment $\left(4^{\circ} \mathrm{C}\right.$ and $\left.52 \% \mathrm{RH}\right)$ prior to the commencement of the experiments. Three different particle size distribution and moisture content levels were used so as to investigate their influence on the physical properties of the biomass compact.

\section{Experimental plan}

In other to investigate the effects of the operating variables on the dependent variable physical properties (density, durability, and dimensional stability) of biomass compact, the experiment was design to densify the biomass samples under three pressure levels $(7.5,10,12.5 \mathrm{MPa})$ and three levels of temperature $\left(90,110,130^{\circ} \mathrm{C}\right)$, while keeping the retention time of chopped biomass in the barrel at $30 \pm 2$ seconds. Table 1 depicts the experimental design for ANOVA analysis and for developing response surface models. 
Table 1: Actual and coded levels for response surface analysis.

\begin{tabular}{lcccc}
\hline Independent variables & Code & \multicolumn{3}{c}{ Coded levels } \\
\hline Temperature, ${ }^{\circ} \mathrm{C}$ & & -1 & 0 & 1 \\
Moisture content (\%) & $\mathrm{x}_{1}$ & 90 & 110 & 130 \\
Pressure (MPa) & $\mathrm{x}_{2}$ & 9 & 12 & 15 \\
Particle Size (mm) & $\mathrm{x}_{3}$ & 7.5 & 10 & 12.5 \\
\hline
\end{tabular}

The combination of the four independent variables yields 27 experiments (table 2). Ten replications were performed on each of the 27 experiments. Using the four chopped biomass residues, a total of 1080 experiments were carried out.

\section{Equipment}

A laboratory hydraulic press briquetting machine was used to study the compression characteristics of the selected agricultural biomass residues. This briquetting machine has a cylindrical die that moves through a barrel surrounded by cylindrical wall. The compartment is connected to a heater, which serves as source of heat to the chopped biomass. Six type ' $T$ ' thermocouples were installed on the cubing die to measure and control its temperature. Five out of the six thermocouples were connected to the data acquisition system, while the sixth one was connected to a temperature controller (thermostat). On the other end of the six thermocouples, four were used to sense the die core temperature, while the other two were installed on the outer surface of the cylinder and linked to a temperature controller to regulate the power input to the heater. Pressure transducers were connected to the top and bottom of the cubing press to measure the densification pressure. Both pressure transducers were calibrated to measure pressures in the range of $0-17.24 \mathrm{Mpa}(0-2500 \mathrm{psi})$. The amplifier linked to the compartment is used to get an output voltage in the range of $0-5 \mathrm{~V}$. The amplifier produces $1 \mathrm{~V}$ for each 3.45 Mpa (500 psi) (briquetting manual). Table 2 indicates the Box-Behnken experimental design followed for the briquetting studies on wheat, barley, oak and canola.

Table 2: Box-Behnken design for response surface analysis.

\begin{tabular}{|c|c|c|c|c|}
\hline \multirow[t]{3}{*}{ Expt. $\mathrm{N}$} & \multicolumn{2}{|c|}{$\begin{array}{r}\text { Process variables } \\
\end{array}$} & \multirow[b]{2}{*}{ Pressure (MPa) } & \multirow[b]{2}{*}{ Particle size $(\mathrm{mm})$} \\
\hline & Temperature $\left({ }^{\circ} \mathrm{C}\right)$ & Moisture content (\%) & & \\
\hline & $\mathrm{x}_{1}$ & $x_{2}$ & $x_{3}$ & $\mathrm{x}_{4}$ \\
\hline 1 & 0 & 0 & 0 & 0 \\
\hline 2 & -1 & 1 & 0 & 0 \\
\hline 3 & 0 & 0 & 1 & -1 \\
\hline 4 & 1 & 0 & -1 & 0 \\
\hline 5 & 0 & 0 & 0 & 0 \\
\hline 6 & 0 & 0 & -1 & -1 \\
\hline 7 & -1 & 0 & 1 & 0 \\
\hline 8 & 1 & 0 & 0 & 1 \\
\hline 9 & 0 & 1 & 1 & 0 \\
\hline 10 & -1 & 0 & 0 & 1 \\
\hline 11 & 0 & 0 & 1 & 1 \\
\hline 12 & -1 & -1 & 0 & 0 \\
\hline 13 & -1 & 0 & -1 & 0 \\
\hline 14 & 0 & -1 & 0 & -1 \\
\hline 15 & 0 & -1 & 0 & 1 \\
\hline
\end{tabular}




\begin{tabular}{lllll}
\hline 16 & 0 & 0 & 0 & 0 \\
17 & 1 & -1 & 0 & 0 \\
18 & 1 & 0 & 0 & -1 \\
19 & -1 & 0 & 0 & -1 \\
20 & 0 & 1 & 0 & -1 \\
21 & 0 & 0 & -1 & 1 \\
22 & 0 & -1 & -1 & 0 \\
23 & 1 & 0 & 1 & 0 \\
24 & 0 & -1 & 1 & 0 \\
25 & 0 & 1 & -1 & 0 \\
26 & 1 & 1 & 0 & 0 \\
27 & 0 & 1 & 0 & 1 \\
\hline
\end{tabular}

\section{Briquette process}

The mass of samples used for making compacts was $10 \pm 0.05 \mathrm{~g}$. Three preset loads of 237.34 , 316.5 , and $395.63 \mathrm{~N}$ corresponding to pressures of $7.5,10$, and $12.5 \mathrm{MPa}$, respectively, were used to compress samples in the barrel. After compression, once the preset load is attained, the plunger was retained in place for $30 \pm 2 \mathrm{~s}$ in order to avoid spring-back effect of the chopped biomass (Mani et al. 2006b), and also to realized the three main stages of biomass densification, which are: a) particle rearrangement, b) elastic and plastic deformation, and c) mechanical interlocking of particles and local melting of some constituents (Tabil 1996). Thereafter, the compact was ejected out of the barrel by using the plunger. Ten replicates (briquettes) were made using each of the treatment combination as explained above for each straw samples, amounting to 270 experiments for each biomass residue and a total of 1080 experiments for the four samples (barley, canola, oat, and wheat straw). After compression, the dimensions (height and diameter) and mass of all the compacts were measured to determine the density in $\mathrm{kg} / \mathrm{m}^{3}$. Samples were then stored in Ziploc bags at a controlled environment for two weeks.

\section{Physical properties}

The durability of the compacts represents the measure of shear and impact forces that it could withstand in the course of handling, storage, and transportation process (Adapa et al. 2009b). Durability, dimensional stability, and moisture content tests were conducted after two weeks of storage of the briquettes. The dimensional stability was calculated based on percentage change in density of the compacts after two weeks of storage, which corresponds to changes in dimensions of the compacts. The compact durability was tested based on American Society of Agricultural and Biological Engineers (ASABE) Standard S269.4 (ASABE 2007), by tumbling 10 briquettes (representing the 10 replicates of each combination) in durability tester for cubes for 3 $\mathrm{min}$ at $40 \mathrm{rev} / \mathrm{min}$. A size distribution index of the durability testing was also obtained. The moisture content of the compacts after durability test was determined based on ASABE Standard S358.2 (ASABE 2006). The unit densities of each of the compact were calculated based on ASABE Standard S269.4 (ASABE 2007), by direct measurement method. The average values of each of the 10 replicates were calculated and used for the analysis in the following section.

\section{Response surface models}

Second order response surface model was developed for the briquetting process variables like temperature $\left(\mathrm{x}_{1}\right)$, moisture content $\left(\mathrm{x}_{2}\right)$, pressure $\left(\mathrm{x}_{3}\right)$ and particle size $\left(\mathrm{x}_{4}\right)$. Equation 1 indicates 
the response surface model developed for initial bulk density, final bulk density, moisture content, durability index and size distribution index of the briquette produced.

$$
y=b 0+\sum_{i=1}^{n} b_{i} x_{i}+\sum_{i=1}^{n} b_{i i} x_{i}{ }^{2}+\sum_{i=1}^{n} \sum_{j=1}^{n} b_{i j} x_{i} x_{j}+\varepsilon
$$

where $y$ is the dependent variable (observed), $x i$ and $x j$ are the coded independent variables, b0, bi, bj are coefficients, $\mathrm{n}$ is the number of independent variables and $\in$ is a random error. The significance of the linear, quadratic and interactive terms was evaluated based on the Fvalue (as a thumb rule F-value should be more than 1.00 (Myers, 1971). In general the response surface models are used in process and product development in chemical and biological engineering problems (Khuri and Cornell, 1987). Statistica software (release 7, 2004 edition, Statsoft, Tulsa, OK, USA) was used to develop the response surface models.

\section{RESULTS AND DISCUSSION}

The average densities, durability rating, and size distribution index of barley, canola, oat, and wheat briquettes are presented in table 3 ( $a \& b)$, the average moisture contents after the durability test are also listed. Figure 1 shows compacts manufactured using canola straw sample at temperature of $130^{\circ} \mathrm{C}, 12 \%$ (w.b.) moisture content, pressure of $10 \mathrm{MPa}$, and 31.75 $\mathrm{mm}$ particle size. The combination of the four independent variables produced compacts with different physical qualities. The results showed that moisture content plays a predominant role in biomass densification process. Densities of biomass compacts decreased with increasing moisture content. Compacts with low moisture content $9 \%$ yields maximum densities as high as $729 \mathrm{~kg} / \mathrm{m}^{3}$ for barley, $747 \mathrm{~kg} / \mathrm{m}^{3}$ for canola, $714 \mathrm{~kg} / \mathrm{m}^{3}$ for oat, and $788 \mathrm{~kg} / \mathrm{m}^{3}$ for wheat. Samples with $12 \%$ moisture content results in lower densities, while $15 \%$ moisture produced the lowest densities with more cracks observed on the surface. Grover and Mishra (1996) reported that low feed moisture content ( $8 \& 10 \%$ ) is required for the manufacture of biomass briquette free of cracks. Low moisture content $(9 \%)$ provides the optimal condition for the particles to bind together by enhancing the binding properties of the material. Higher moisture content $(15 \%)$ results in the expansion of the compact volume, therefore causing a decrease in the compact density. Similar result has been reported by Colley et al. (2006). Table 3a gives the physical properties of the briquettes of barley and canola and table $3 \mathrm{~b}$ gives properties of oat and wheat.

In this study, the least durability rating was produced at $15 \%$ moisture. This investigation indicates that higher pressure can produce better compact only if optimal combination with other independent variables is made. It shows that even at low and moderate pressures $(7.5 \& 10$ $\mathrm{MPa}$, respectively) good quality compact can be obtained at $9 \%$ moisture. This implies that energy cost incurred by high pressure application during the densification process can be reduced if biomass with optimal moisture is used. Applied pressure has the highest effect on the total energy consumption as reported by Mani et al. (2006a). At high moisture content (15\%), water acts as a lubricant and reduces the binding property of the material even at high pressure of $12.5 \mathrm{Mpa}$; this resulted to the production of poor quality and low briquette density. Similar finding has been reported by Mani et al. (2006a) on chopped corn stover pellet. 


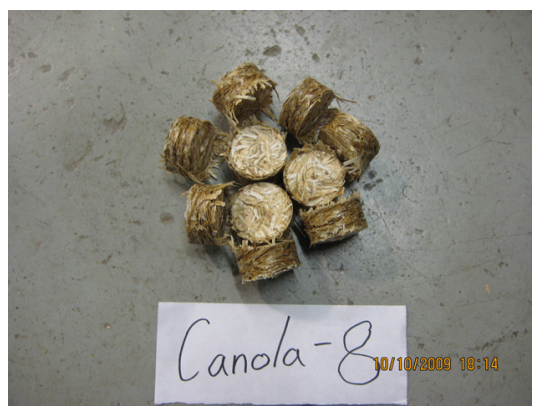

before durability test

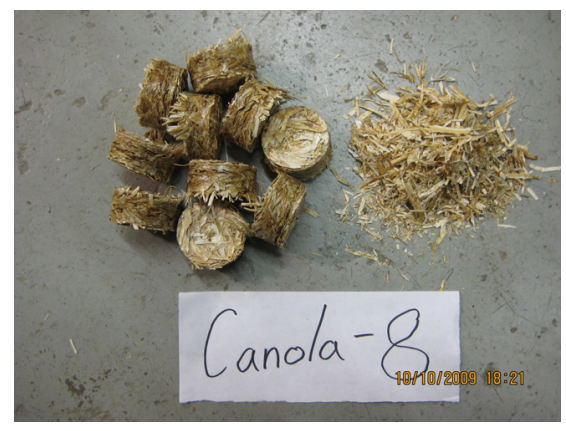

after durability test

Figure 1 Canola straw briquettes before and after durability test.

Table 3a Physical properties of the briquette (barley and canola)

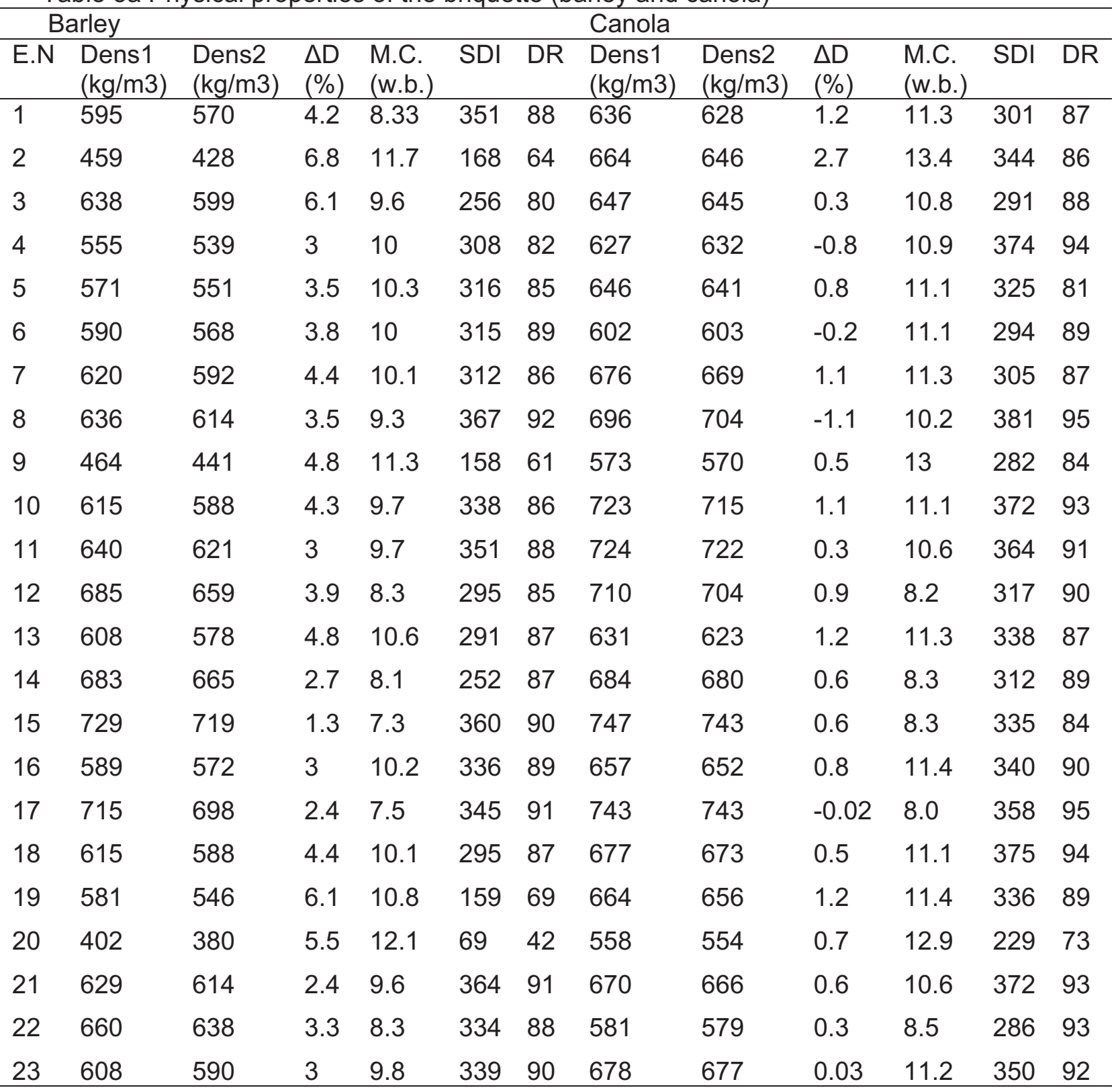




\begin{tabular}{lllllllllllll}
\hline 24 & 705 & 687 & 2.6 & 8.1 & 315 & 89 & 726 & 726 & 0.1 & 8.4 & 365 & 91 \\
25 & 447 & 425 & 5 & 12.4 & 175 & 73 & 563 & 561 & 0.4 & 12.8 & 360 & 90 \\
26 & 455 & 433 & 4.9 & 11.6 & 194 & 73 & 587 & 587 & 0.002 & 12.9 & 303 & 92 \\
27 & 475 & 432 & 9 & 12.3 & 228 & 71 & 579 & 573 & 0.9 & 13 & 364 & 91 \\
\hline
\end{tabular}

Table 3b Physical properties of the briquette (oat and wheat)

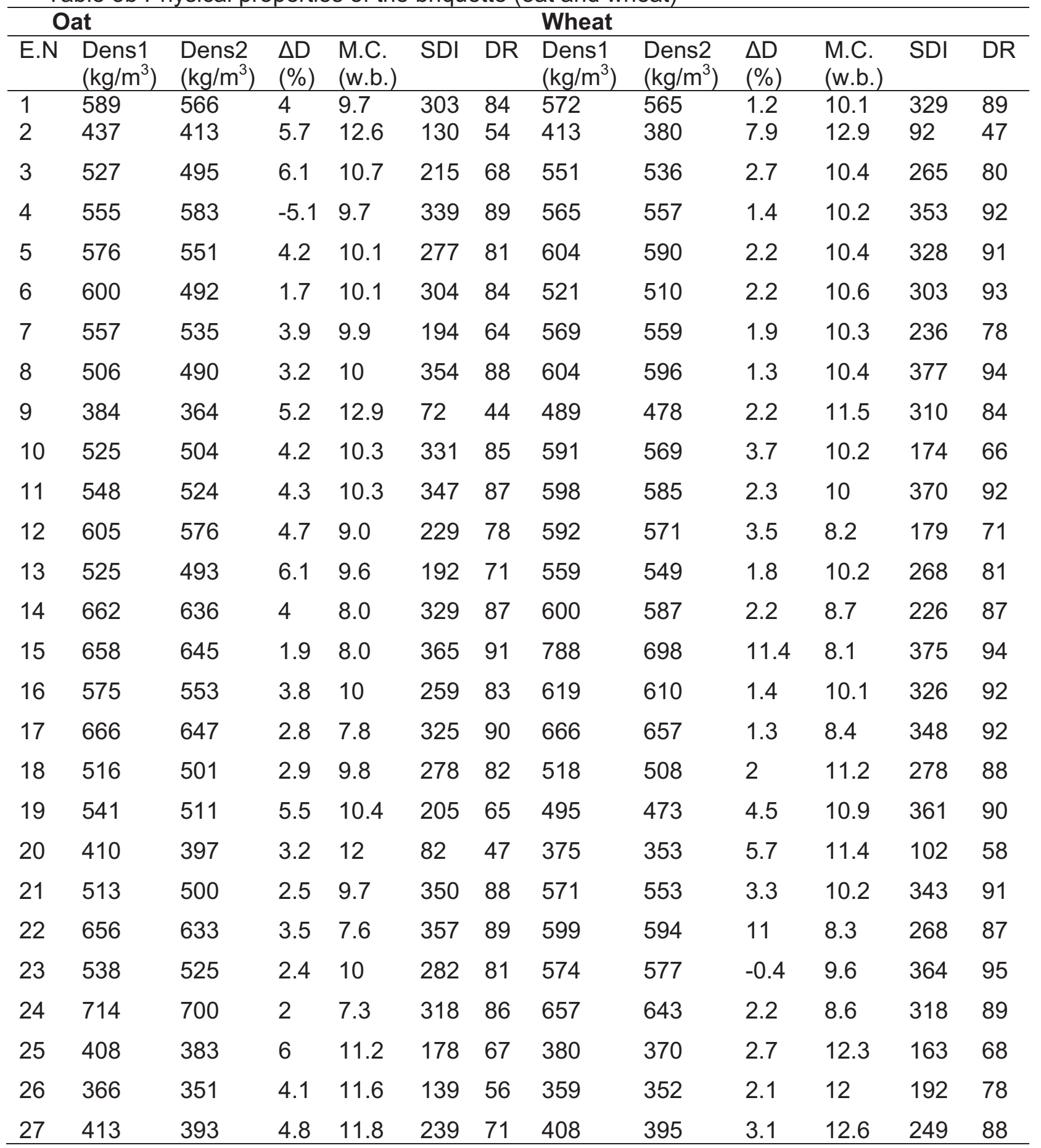




\author{
Note: \\ E.N: $\quad$ Experiment number \\ Dens1: Average density $\left(\mathrm{kg} / \mathrm{m}^{3}\right)$ of briquettes after briquetting, with number of replicates, $\mathrm{n}=10$ \\ Dens2: Average density $\left(\mathrm{kg} / \mathrm{m}^{3}\right)$ of briquettes after 2 weeks of storage, with $\mathrm{n}=10$ \\ $\triangle \mathrm{D}: \quad \%$ change in density after 2 weeks (dimensional stability) \\ M.C.: $\quad$ Average moisture content (\% w.b.) after 2 weeks of storage, with $n=10$ \\ SDI: $\quad$ Size distribution index, with $n=10$ \\ DR: Durability rating, with $\mathrm{n}=10$
}

Briquette durability rating observed was in the range between 42-92 for barley, 72-95 for canola, 43-91 for oat, and $45-95$ for wheat, see table 3 (a \& b). At high temperature $\left(130^{\circ} \mathrm{C}\right.$ ) and low moisture (9-12\%), compacts with high durability rating were produced. At this temperature, the melting points of some constituents such as lignin was approached, alongside with local melting of the materials, this causes binding of the particles and production of compact that was able to withstand the shear, impact, tumbling, rotation and other forces during the durability test. This work shows that high temperature $\left(130^{\circ} \mathrm{C}\right)$ with high moisture content $(15 \%)$ resulted in the least density. Durability rating is dependent on local melting of some constituent of biomass compacts during densification at the required moisture. A briquette with low density may withstand the shear and rotation during handling and transportation better than briquette with high density; inasmuch as melting points of biomass constituents is approached during densification. This implies that high temperature may not guarantee the production of briquette with high density, but may guarantee compact with high durability rating. Biomass produced at too low temperature may lead to disintegration of the briquettes during handling and transportation processes. Combination of low moisture $(9 \%)$ and high pressure resulted in higher durability. However, in some cases the durability decreased at higher pressure (12.5 MPa) due to high moisture (15\%) and surface cracks. Similar observation has been reported by Mani et al. (2004b). High moisture (15\%) is predominantly responsible for low durable compact.

The size distribution index (SDI) is a reflection of how many number of compact (for this case, the ten replicates) are able to withstand the shear, impact and rotation during handling, transportation and usage (for this case, during the durability test). SDI has a direct correlation with the durability. The values obtained ranges from 69-367 for barley, 229-381 for canola, 72366 for oat, and 92-377 for wheat.

Almost in all cases, there was decreased in density of the compact after 2 weeks of storage. The reason for this was due to the dimensional instability which was more significant in the axial direction (height) as compare to the lateral direction (diameter), which in some cases tended to be nil depending on the combination of the material and operating variables. Similar trend of expansion have also been reported by Mani et al. (2004b) on compaction of corn stover and AlWidyan et al. (2002) on physical durability and stability of olive cake briquettes. The dimensional stability is mainly dependent on the available moisture content and pressure. The change in density is more significant at $15 \%$ moisture and pressure of $7.5 \mathrm{Mpa}$. The high moisture content and low pressure does not provide the enabling condition for mechanical interlocking and the binding effect of the constituents. The dimensional stability of the biomass briquette was determined in terms of density change after 2 weeks of storage. Since the mass of all the briquettes are the same and the briquette density was calculated from the dimensions. Therefore, any dimensional expansion or change will directly have equivalent effect on the density. The change in briquette density for barley was between $1.3-9 \%, 0-2.7 \%$ for canola, 0 $6.1 \%$ for oat, and $0-11.4 \%$ for wheat. $9 \%$ moisture and $12.5 \mathrm{Mpa}$ pressure generate compact with higher density stability.

Particle size play a role in the densification process, however, in this study the effect is not as significant as moisture content, pressure and temperature, because of the large particle size of 
the materials used. Al-Widyan et al. (2002) also reported the high influence of moisture content on the durability of biomass briquettes. Tabil (1996) and Kaliyan and Morey (2009) cited that large/coarse ground materials tend to produce less quality compacts because they may create natural fissure points that cause cracks and fractures.

Canola straw produced briquettes with higher density, stability and durability at low moisture as compare to the other three biomass straws, therefore, the optimal condition required to manufacture briquette with high quality is different for each biomass feedstock.

\section{ANOVA analysis}

To further confirm the effects of the material and process variables, statistical analysis was performed using SAS software. Analysis of variance (ANOVA) was done on the experimental data on the different physical quality parameter of briquettes from the four biomass feedstocks. Tables $4,5,6,7$ and 8 are the ANOVA of the properties initial bulk density, final bulk density after two weeks of storage, moisture content, durability index and size distribution index for wheat barley, oat and canola straws.

Table 4. ANOVA analyses initial bulk density

\begin{tabular}{|c|c|c|c|c|}
\hline \multicolumn{5}{|c|}{ Raw material } \\
\hline Process variable & Wheat & Barley & Oat & Canola \\
\hline \multicolumn{5}{|l|}{ Linear } \\
\hline $\mathrm{x}_{1}$ & ns & ns & ns & ns \\
\hline$x_{2}$ & $(-)^{* * *}$ & $(-)^{* * *}$ & $(-)^{\star * *}$ & $(-)^{\star * *}$ \\
\hline$x_{3}$ & $(+)^{*}$ & $(+)^{* *}$ & $(+)^{*}$ & $(+)^{* * *}$ \\
\hline $\mathrm{x}_{4}$ & $(+)^{* * *}$ & $(+)^{* *}$ & $(+)^{* *}$ & $(+)^{* * *}$ \\
\hline \multicolumn{5}{|l|}{ Quadratic } \\
\hline$x_{1}^{2}$ & $(-)^{*}$ & ns & ns & $(+)^{\star \star *}$ \\
\hline$x_{2}^{2}$ & $(-)^{* *}$ & $(-)^{* *}$ & $(-)^{* *}$ & ns \\
\hline$x_{3}^{2}$ & ns & ns & Ns & ns \\
\hline$x_{4}^{2}$ & ns & $(+)^{* *}$ & $(+)^{*}$ & $(+)^{\star *}$ \\
\hline \multicolumn{5}{|l|}{ Interactive } \\
\hline$x_{1} x_{2}$ & $(-)^{*}$ & ns & ns & $(-)^{*}$ \\
\hline$x_{1} x_{3}$ & ns & ns & ns & ns \\
\hline$x_{1} x_{4}$ & ns & ns & ns & ns \\
\hline$x_{2} x_{3}$ & ns & ns & ns & ns \\
\hline $\mathrm{x}_{2} \mathrm{x}_{4}$ & $(-)^{*}$ & ns & ns & ns \\
\hline$x_{3} x_{4}$ & ns & ns & ns & ns \\
\hline
\end{tabular}

Table 5. ANOVA analysis of final bulk density after two weeks of storage

\begin{tabular}{|c|c|c|c|c|}
\hline \multicolumn{5}{|c|}{ Raw material } \\
\hline Process variable & Barley & Canola & Oat & Wheat \\
\hline \multicolumn{5}{|l|}{ Linear } \\
\hline$x_{1}$ & ns & ns & Ns & ns \\
\hline$x_{2}$ & $(-)^{\star \star \star}$ & $(-)^{\star * \star}$ & $(-)^{* \star \star}$ & $(-)^{\star * *}$ \\
\hline$x_{3}$ & $(+)^{*}$ & $(+)^{\star \star \star *}$ & Ns & $(+)^{*}$ \\
\hline $\mathrm{X}_{4}$ & $(+)^{*}$ & $(+)^{* \star}$ & Ns & $(+)^{* *}$ \\
\hline \multicolumn{5}{|l|}{ Quadratic } \\
\hline$x_{1}^{2}$ & ns & $(+)^{* *}$ & $(-)^{*}$ & $(-)^{*}$ \\
\hline$x_{2}^{2}$ & $(-)^{*}$ & ns & $(-)^{*}$ & $(-)^{* *}$ \\
\hline$x_{3}^{2}$ & ns & ns & Ns & ns \\
\hline$x_{4}^{2}$ & ns & $(+)^{*}$ & $(-)^{*}$ & $(-)^{*}$ \\
\hline
\end{tabular}




\begin{tabular}{lllll}
\hline Interactive & & & & \\
\cline { 1 - 2 } $\mathrm{x}_{1} \mathrm{x}_{2}$ & $\mathrm{~ns}$ & $(-)^{*}$ & $(-)^{*}$ & $\mathrm{~ns}$ \\
$\mathrm{x}_{1} \mathrm{x}_{3}$ & $\mathrm{~ns}$ & $\mathrm{~ns}$ & $\mathrm{~ns}$ & $\mathrm{~ns}$ \\
$\mathrm{x}_{1} \mathrm{x}_{4}$ & $\mathrm{~ns}$ & $\mathrm{~ns}$ & $\mathrm{~ns}$ & $\mathrm{~ns}$ \\
$\mathrm{x}_{2} \mathrm{x}_{3}$ & $\mathrm{~ns}$ & $(-)^{* *}$ & $\mathrm{~ns}$ & $\mathrm{~ns}$ \\
$\mathrm{x}_{2} \mathrm{x}_{4}$ & $\mathrm{~ns}$ & $\mathrm{~ns}$ & $\mathrm{~ns}$ & $\mathrm{~ns}$ \\
$\mathrm{x}_{3} \mathrm{x}_{4}$ & $\mathrm{~ns}$ & $\mathrm{~ns}$ & $\mathrm{~ns}$ & $\mathrm{~ns}$ \\
\hline
\end{tabular}

Table 6. ANOVA analysis of moisture content

\begin{tabular}{|c|c|c|c|c|}
\hline \multicolumn{5}{|c|}{ Raw material } \\
\hline Process variable & Barley & Canola & Oat & Wheat \\
\hline \multicolumn{5}{|l|}{ Linear } \\
\hline $\mathrm{x}_{1}$ & ns & $(-)^{*}$ & $(-)^{*}$ & ns \\
\hline$x_{2}$ & $(+)^{* * *}$ & $(+)^{* * *}$ & $(+)^{* * *}$ & $(+)^{* * *}$ \\
\hline$x_{3}$ & $(-)^{*}$ & ns & $(+)^{*}$ & $(-)^{*}$ \\
\hline$x_{4}$ & $(+)^{*}$ & $(-)^{*}$ & ns & $(-)^{*}$ \\
\hline \multicolumn{5}{|l|}{ Quadratic } \\
\hline$x_{1}^{2}$ & ns & ns & ns & ns \\
\hline$x_{2}^{2}$ & ns & $(-)^{* * *}$ & ns & ns \\
\hline$x_{3}^{2}$ & $(+)^{*}$ & ns & ns & ns \\
\hline$x_{4}^{2}$ & ns & $(-)^{*}$ & ns & ns \\
\hline \multicolumn{5}{|l|}{ Interactive } \\
\hline $\mathrm{x}_{1} \mathrm{x}_{2}$ & $(+)^{*}$ & ns & ns & $\mathrm{ns}$ \\
\hline$x_{1} x_{3}$ & ns & ns & ns & ns \\
\hline $\mathrm{X}_{1} \mathrm{X}_{4}$ & ns & ns & ns & $(-)^{*}$ \\
\hline$x_{2} x_{3}$ & ns & ns & $(+)^{*}$ & ns \\
\hline$x_{2} X_{4}$ & ns & ns & ns & $(+)^{*}$ \\
\hline$x_{3} X_{4}$ & ns & ns & ns & ns \\
\hline
\end{tabular}

Table 7. ANOVA analysis of durability index.

\begin{tabular}{|c|c|c|c|c|}
\hline \multicolumn{5}{|c|}{ Raw material } \\
\hline Process variable & Barley & Canola & Oat & Wheat \\
\hline \multicolumn{5}{|l|}{ Linear } \\
\hline $\mathrm{x}_{1}$ & $(+)^{*}$ & $(+)^{*}$ & $(+)^{* * *}$ & $(+)^{*}$ \\
\hline$x_{2}$ & $(-)^{* * *}$ & $(-)^{*}$ & $(-)^{* * *}$ & $(-)^{*}$ \\
\hline$x_{3}$ & ns & ns & $(-)^{\star \star \star}$ & ns \\
\hline $\mathrm{x}_{4}$ & $(+)^{\star *}$ & $(+)^{*}$ & $(+)^{\star \star *}$ & $(+)^{*}$ \\
\hline \multicolumn{5}{|l|}{ Quadratic } \\
\hline$x_{1}^{2}$ & ns & $(+)^{*}$ & $(-)^{* *}$ & $(+)^{*}$ \\
\hline$x_{2}^{2}$ & $(-)^{* * *}$ & ns & $(-)^{* * *}$ & ns \\
\hline$x_{3}^{2}$ & ns & ns & Ns & ns \\
\hline$x_{4}^{2}$ & ns & ns & Ns & ns \\
\hline \multicolumn{5}{|l|}{ Interactive } \\
\hline $\mathrm{x}_{1} \mathrm{x}_{2}$ & ns & ns & $(-)^{*}$ & ns \\
\hline$x_{1} x_{3}$ & ns & ns & ns & ns \\
\hline $\mathrm{X}_{1} \mathrm{X}_{4}$ & ns & ns & $(-)^{\star}$ & ns \\
\hline$x_{2} x_{3}$ & ns & ns & $(-)^{* *}$ & ns \\
\hline $\mathrm{X}_{2} \mathrm{X}_{4}$ & $(+)^{*}$ & $(+)^{* *}$ & $(+)^{* *}$ & $(+)^{* *}$ \\
\hline$x_{3} x_{4}$ & ns & ns & $(+)^{*}$ & ns \\
\hline
\end{tabular}

Table 8. ANOVA analysis of the experimental data on size distribution index 


\begin{tabular}{|c|c|c|c|c|}
\hline \multicolumn{5}{|c|}{ Raw material } \\
\hline Process variable & Barley & Canola & Oat & Wheat \\
\hline \multicolumn{5}{|l|}{ Linear } \\
\hline $\mathrm{x}_{1}$ & $(+)^{* *}$ & ns & $(+)^{* * *}$ & ns \\
\hline$x_{2}$ & $(-)^{* * *}$ & ns & $(-)^{* * *}$ & ns \\
\hline$x_{3}$ & ns & ns & $(-)^{\star *}$ & ns \\
\hline $\mathrm{x}_{4}$ & $(+)^{* * *}$ & $(+)^{* * *}$ & $(+)^{* * *}$ & $(+)^{\star * *}$ \\
\hline \multicolumn{5}{|l|}{ Quadratic } \\
\hline$x_{1}{ }^{2}$ & ns & $(+)^{*}$ & $(-)^{*}$ & $(+)^{*}$ \\
\hline$x_{2}^{2}$ & $(-)^{* * *}$ & ns & $(-)^{* * *}$ & ns \\
\hline$x_{3}^{2}$ & ns & ns & ns & ns \\
\hline$x_{4}^{2}$ & $(-)^{*}$ & ns & $(+)^{*}$ & ns \\
\hline \multicolumn{5}{|l|}{ Interactive } \\
\hline $\mathrm{x}_{1} \mathrm{x}_{2}$ & ns & $(-)^{*}$ & ns & $(-)^{*}$ \\
\hline$x_{1} x_{3}$ & ns & ns & ns & ns \\
\hline $\mathrm{X}_{1} \mathrm{X}_{4}$ & $(-)^{*}$ & ns & ns & ns \\
\hline$x_{2} x_{3}$ & ns & $(-)^{* *}$ & ns & $(-)^{* *}$ \\
\hline $\mathrm{X}_{2} \mathrm{X}_{4}$ & ns & $(+)^{*}$ & $(+)^{*}$ & $(+)^{*}$ \\
\hline$x_{3} x_{4}$ & ns & ns & ns & ns \\
\hline
\end{tabular}

Note: ${ }^{* * *}=\mathrm{P}<0.01 ;{ }^{* *}=\mathrm{P}<0.05 ;{ }^{*}=\mathrm{P}<0.1$; ns: non-significant

The analysis indicated that temperature $\left(\mathrm{x}_{1}\right)$ during briquetting has no significant (ns) difference on the initial and final densities (density after briquetting and after two weeks of storage, respectively) of barley, canola, oat, and wheat straw briquettes (table 4). The results show that moisture content $\left(x_{2}\right)$ (M.C.) of the four feedstock's is extremely significant $(p<0.01)$ on the initial and final densities irrespective of the type of feedstock's. This implies that the effect of M.C. on density of briquette will almost be the same if the experiments are repeated. The result reflects the significant role and binding characteristics of M.C. during the densification process. ANOVA analysis showed that M.C. negatively correlated with the briquette density, which confirms that increasing the moisture content resulted in the decrease of briquette density. A similar result has been reported by Colley et al. (2006) and Mani et al. (2006a). It demonstrated that optimal M.C. enhances binding characteristics, which is required for the formation of briquette with good dimensional stability during the storage period (in this case, two weeks of storage). The applied pressure $\left(x_{3}\right)$ and particle size $\left(x_{4}\right)$ affect the density of briquette differently. This may be due to differences in chemical compositions of biomass feedstock. The effect of pressure on the initial density of barley straw briquettes is highly significant $(p<0.05)$, but statistically significant $(p<0.1)$ on the final density, extremely significant on the initial and final density of canola straw briquettes, statistically significant on the initial density of oat straw briquettes with no significant on the final density, and statistically significant on the initial and final density of wheat straw briquettes. These results indicate that the effect of M.C. is more significant than that of applied pressure for the formation of briquette with higher density, except for the case of canola where both effects are similar. Pressure presents a positive correlation with density of briquettes (i.e. the higher the pressure, the higher the density), except for the final density of oat where it has no significant. Particle size of the biomass straw is extremely significant on the initial density of canola and wheat, and highly significant on barley and oat straw briquettes. It is highly significant on the final density of canola and wheat, statistically significant on barley but not significant on oat. The particle size is positively correlated with the initial and final density, except for the final density of oat, where it is not significant. This correlation may be due to the combination of large particle size of materials with other variables used in this experiment. This implies that large particle size can produce briquette with high density inasmuch as appropriate combination with moisture and 
pressure is made. This result is in contrast with the studies of Kaliyan and Morey (2006) and Sokhansanj et al. (2005) that used particle size of 0.56 to $0.8 \mathrm{~mm}$, and $3.2 \mathrm{~mm}$ and $0.8 \mathrm{~mm}$, respectively, in their investigations.

The analysis demonstrates that temperature has inverse correlation and statistically significant effect on the M.C. of canola and oat briquettes, but has no significant effect on barley and wheat briquettes. The initial moisture of the four feedstocks has positive correlation and extremely significant effect on the M.C. of the briquette. Pressure and particle size also affected the M.C. of the briquette differently. The response depends on the type of biomass feedstocks.

ANOVA showed that temperature has positive correlation with durability rating (DR) of biomass briquette, while M.C. has inverse correlation. High temperature used in producing briquettes resulted in better durability, which made the briquettes to withstand the shear, impact, tumbling, and rotation during the DR test. These results confirm the high values of DR in table 3 (a \& b), where high briquetting temperature $\left(130^{\circ} \mathrm{C}\right)$ with appropriate treatment combination with other material and process variables resulted in high durability briquettes. The reason for this may be due to the local melting of biomass constituents such as lignin and the occurrence of solid bridges at elevated temperature during densification process. These determine the strength and extend of durability of the final densified product as reported by Ghebre-Sellassie (1989). Under high temperature $\left(130^{\circ} \mathrm{C}\right)$, these constituents act as adhesive binders and provide bonding effect. This analysis demonstrated that the higher the M.C. of biomass feedstocks, the lower the DR, because at high M.C., the residual moisture in the feedstock turns to steam during compression, which acts as a lubricant and tends to decrease the binding between particles even at high pressure. Similar result has been reported by Mani et al. (2006b). At high M.C., the natural binders (such as lignin) in biomass are possibly not completely released, and prevented from complete flattening due to the incompressibility nature of water, coupled with moisture that are trapped within the particles as explained by Kaliyan and Morey (2006). Temperature is extremely significant on the DR of oat and statistically significant on barley, canola, and wheat straw briquettes. While, M.C. is extremely significant on the DR of barley and oat, and statistically significant on canola and wheat. However, densification pressure has no significant effect on the DR of barley, canola, and oat straw briquettes, but extremely significant and inversely correlated with oat briquettes. The results also depict that particle size has positive correlation with DR of briquettes. The reason for this may be also due to the large particle size of the materials used in this experiment. With optimal combinations with other variables, large particle size resulted in high DR (table 3 a \& b). Larger particle size seems to be highly diverse with more particle rearrangement during densification, thereby enhancing better particle binding and compaction. Using chopped large particle size with appropriate combination with other material and process variables could help in cost reduction. Mani et al. (2004a) and Kaliyan and Morey (2006) reported that the energy consumption for grinding increases as the particle size of the ground biomass becomes finer. Since briquette is required for direct combustion, chopped large particle size $(25-32 \mathrm{~mm})$ can be used for briquette formation, while, avoiding the high cost of milling or grinding. Therefore, to produce briquette at low production cost, with better durability and stability qualities, that could withstand the handling during storage and shear, impact, tumbling, and rotation during transportation, high temperature, low M.C., and large particle size with appropriate combination with the densification pressure are needed, so as to make biomass competitive with fossil fuels.

Briquette durability rating observed was in the range between 42-92 for barley, 72-95 for canola, 43-91 for oat, and 45-95 for wheat (table 3 a \& b). At high temperature $\left(130^{\circ} \mathrm{C}\right)$ and low moisture $(9-12 \%)$, compacts with high durability rating were produced. At this temperature, the melting points of some constituents such as lignin was approached, alongside with local melting of other 
materials, this causes binding of the particles and production of compact that was able to withstand the shear, impact, tumbling, rotation, and other forces during the durability test. This work demonstrated that high temperature $\left(130^{\circ} \mathrm{C}\right)$ with high moisture content $(15 \%)$ resulted in the least density. Durability rating is dependent on local melting (which depends on temperature) of some constituent of biomass feedstocks during densification process at satisfactory and required moisture content. This study indicated that briquette with low density may withstand the shear and rotation during handling and transportation better than briquette with high density; inasmuch as melting points of biomass constituents was approached during densification. This implies that high temperature may not guarantee the production of briquette with high density, but may guarantee compact with high durability rating. Biomass produced at too low temperature may lead to disintegration of the briquettes during handling and transportation processes. Combination of low moisture (9\%) and appropriate pressure resulted in high durability. However, in some cases the durability decreased at higher pressure (12.5 MPa) due to high moisture (15\%) and surface cracks. Similar observation has been reported by Mani et al. (2004b). High moisture (15\%) is predominantly responsible for low durable compact. Al-Widyan et al. (2002) also reported the high influence of moisture content on the durability of biomass briquettes.

\section{Response surface models}

Response models were developed for the properties initial bulk density, final bulk density, moisture content, durability index and size distribution index. The below are the response surface models developed for barely, canola, oat and wheat straws for the process variables under study in coded form.

\section{Barley straw}

Initial BD $\left(\mathrm{kg} / \mathrm{m}^{3}\right)=585+1.34 \mathrm{x}_{1}-122.9 \mathrm{x}_{2}+15.5 \mathrm{x}_{3}+17.91 \mathrm{x}_{4}+9.25 \mathrm{x}_{1}{ }^{2}-24.87 \mathrm{x}_{2}{ }^{2}+10.75 \mathrm{x}_{3}{ }^{2}+19.37 \mathrm{x}_{4}{ }^{2}-$ $8.5 x_{1} x_{2}+10.25 x_{1} x_{3}-3.25 x_{1} x_{4}-7.0 x_{2} x_{3}+6.75 x_{2} x_{4}-9.25 x_{3} x_{4}$

Final BD $\left(\mathrm{kg} / \mathrm{m}^{3}\right)=564+5.91 \mathrm{x}_{1}-127.9 \mathrm{x}_{2}+14.0 \mathrm{x}_{3}+20.16 \mathrm{x}_{4}+6.04 \mathrm{x}_{1}^{2}-24.95 \mathrm{x}_{2}^{2}+10.91 \mathrm{x}_{3}^{2}+16.16 \mathrm{x}_{4}^{2}-$ $8.5 x_{1} x_{2}+9.25 x_{1} x_{3}-4.0 x_{1} x_{4}-8.25 x_{2} x_{3}-0.5 x_{2} x_{4}-6.0 x_{3} x_{4}$

MC $(\%)=9.61-0.24 x_{1}+1.98 x_{2}-0.19 .0 x_{3}-0.23 x_{4}+0.20 x_{1}{ }^{2}+0.14 x_{2}{ }^{2}+0.20 x_{3}{ }^{2}+0.09 x_{4}{ }^{2}+0.175 x_{1} x_{2}$

$+0.075 x_{1} x_{3}+0.075 x_{1} x_{4}-0.225 x_{2} x_{3}+0.25 x_{2} x_{4}+0.125 x_{3} x_{4}$

$\left(r^{2}=0.92\right)$

SDI $=279.66+36.33 x_{1}-90.25 x_{2}-24.33 x_{3}+47.75 x_{4}-21.5 x_{1}^{2}-50.87 x_{2}^{2}-2.75 x_{3}^{2}+28.62 x_{4}^{2}-21.75 x_{1} x_{2}$

$-14.75 x_{1} x_{3}-12.75 x_{1} x_{4}-16.75 x_{2} x_{3}+30.25 x_{2} x_{4}+21.5 x_{3} x_{4}$

$\left(r^{2}=0.95\right)$

$\mathrm{DI}=87.33+3.16 \mathrm{x}_{1}-12.16 \mathrm{x}_{2}-1.33 \mathrm{x}_{3}+5.33 \mathrm{x}_{4}-0.54 \mathrm{x}_{1}{ }^{2}-10.29 \mathrm{x}_{2}{ }^{2}+0.95 \mathrm{x}_{3}{ }^{2}-3.04 \mathrm{x}_{4}{ }^{2}+0.75 \mathrm{x}_{1} \mathrm{x}_{2}$

$+2.25 \mathrm{x}_{1} \mathrm{x}_{3}-3.0 \mathrm{x}_{1} \mathrm{x}_{4}-3.25 \mathrm{x}_{2} \mathrm{x}_{3}+6.5 \mathrm{x}_{2} \mathrm{x}_{4}+1.5 \mathrm{x}_{3} \mathrm{x}_{4}$

$\left(r^{2}=0.95\right)$

\section{Canola straw}

Initial BD $\left(\mathrm{kg} / \mathrm{m}^{3}\right)=646.33-5.0 \mathrm{x}_{1}-55.58 \mathrm{x}_{2}+29.16 \mathrm{x}_{3}+25.58 \mathrm{x}_{4}+30.91 \mathrm{x}_{1}^{2}-14.20 \mathrm{x}_{2}^{2}-16.33 \mathrm{x}_{3}^{2}$

$+17.79 x_{4}^{2}-27.5 x_{1} x_{2}+1.5 x_{1} x_{3}-10.0 x_{1} x_{4}-33.75 x_{2} x_{3}-10.5 x_{2} x_{4}+2.25 x_{3} x_{4} \quad\left(r^{2}=0.93\right)$

Final BD $\left(\mathrm{kg} / \mathrm{m}^{3}\right)=640.33+0.25 \mathrm{x}_{1}-57.0 \mathrm{x}_{2}+28.75 \mathrm{x}_{3}+26.0 \mathrm{x}_{4}+31.33 \mathrm{x}_{1}{ }^{2}-14.0 \mathrm{x}_{2}{ }^{2}-13.16 \mathrm{x}_{3}{ }^{2}+19.45 \mathrm{x}_{4}{ }^{2}-$ $24.5 \mathrm{x}_{1} \mathrm{x}_{2}-0.25 \mathrm{x}_{1} \mathrm{x}_{3}-7.0 \mathrm{x}_{1} \mathrm{x}_{4}-34.5 \mathrm{x}_{2} \mathrm{x}_{3}-11.0 \mathrm{x}_{2} \mathrm{x}_{4}+3.5 \mathrm{x}_{3} \mathrm{x}_{4}$ $\left(r^{2}=0.97\right)$

MC $(\%)=11.26-0.2 x_{1}+2.35 x_{2}+0.008 x_{3}-0.15 x_{4}-0.062 x_{1}^{2}-0.475 x_{2}^{2}-0.125 x_{3}^{2}-0.26 x_{4}^{2}-0.075 x_{1} x_{2}$ $+0.075 \mathrm{x}_{1} \mathrm{x}_{3}-0.15 \mathrm{x}_{1} \mathrm{x}_{4}+0.075 \mathrm{x}_{2} \mathrm{x}_{3}+0.025 \mathrm{x}_{2} \mathrm{x}_{4}+0.075 \mathrm{x}_{3} \mathrm{x}_{4}$

$\left(r^{2}=0.98\right)$ 


$$
\begin{aligned}
& \mathrm{SDI}=322+10.75 \mathrm{x}_{1}-7.58 \mathrm{x}_{2}-5.58 \mathrm{x}_{3}+29.25 \mathrm{x}_{4}+24.5 \mathrm{x}_{1}^{2}-12.75 \mathrm{x}_{2}{ }^{2}+3.0 \mathrm{x}_{3}{ }^{2}+8.5 \mathrm{x}_{4}{ }^{2}-20.25 \mathrm{x}_{1} \mathrm{x}_{2} \\
& +2.25 x_{1} x_{3}-7.5 x_{1} x_{4}-39.25 x_{2} x_{3}+28.0 x_{2} x_{4}-1.25 x_{3} x_{4} \\
& \left(r^{2}=0.83\right) \quad \ldots(10) \\
& \mathrm{DI}=86.0+2.5 \mathrm{x}_{1}-2.16 \mathrm{x}_{2}-1.08 \mathrm{x}_{3}+2.08 \mathrm{x}_{4}+4.16 \mathrm{x}_{1}^{2}-0.33 \mathrm{x}_{2}{ }^{2}+2.29 \mathrm{x}_{3}{ }^{2}+1.04 \mathrm{x}_{4}{ }^{2}+0.25 \mathrm{x}_{1} \mathrm{x}_{2} \\
& -0.5 x_{1} x_{3}-0.75 x_{1} x_{4}-1.0 x_{2} x_{3}+5.75 x_{2} x_{4}-0.25 x_{3} x_{4} \\
& \left(r^{2}=0.77\right) \quad \ldots(11)
\end{aligned}
$$

\section{Oat straw}

Initial BD $\left(\mathrm{kg} / \mathrm{m}^{3}\right)=580.0-3.58 \mathrm{x}_{1}-128.58 \mathrm{x}_{2}+0.91 \mathrm{x}_{3}-7.75 \mathrm{x}_{4}-32.45 \mathrm{x}_{1}{ }^{2}-27.20 \mathrm{x}_{2}{ }^{2}-8.95 \mathrm{x}_{3}{ }^{2}$

$-22.2 x_{4}^{2}-33.0 x_{1} x_{2}-12.25 x_{1} x_{3}+1.5 x_{1} x_{4}-20.5 x_{2} x_{3}+1.75 x_{2} x_{4}+27.0 x_{3} x_{4}$

Final BD $\left(\mathrm{kg} / \mathrm{m}^{3}\right)=556.66+5.41 \mathrm{x}_{1}-128.0 \mathrm{x}_{2}+4.91 \mathrm{x}_{3}+2.0 \mathrm{x}_{4}-24.33 \mathrm{x}_{1}{ }^{2}-23.20 \mathrm{x}_{2}{ }^{2}-12.08 \mathrm{x}_{3}{ }^{2}-29.45 \mathrm{x}_{4}{ }^{2}-$ $33.25 \mathrm{x}_{1} \mathrm{x}_{2}-25.0 \mathrm{x}_{1} \mathrm{x}_{3}-1.0 \mathrm{x}_{1} \mathrm{x}_{4}-21.5 \mathrm{x}_{2} \mathrm{x}_{3}-3.25 \mathrm{x}_{2} \mathrm{x}_{4}+5.25 \mathrm{x}_{3} \mathrm{x}_{4}$

MC $(\%)=9.93-0.24 x_{1}+2.03 x_{2}+0.26 x_{3}-0.075 x_{4}+0.10 x_{1}^{2}-0.00417 x_{2}^{2}-0.10 x_{3}^{2}-0.15 x_{4}^{2}+0.05 x_{1} x_{2}$ $+0.075 x_{1} x_{4}+0.5 x_{2} x_{3}-0.05 x_{2} x_{4}$ $\left(r^{2}=0.98\right) \quad \ldots(14)$

$\mathrm{SDI}=279.66+36.33 \mathrm{x}_{1}-90.25 \mathrm{x}_{2}-24.33 \mathrm{x}_{3}+47.75 \mathrm{x}_{4}-21.5 \mathrm{x}_{1}^{2}-50.87 \mathrm{x}_{2}^{2}-2.75 \mathrm{x}_{3}{ }^{2}+28.62 \mathrm{x}_{4}{ }^{2}-21.75 \mathrm{x}_{1} \mathrm{x}_{2}$ $-14.75 x_{1} x_{3}-12.5 x_{1} x_{4}-16.75 x_{2} x_{3}+30.25 x_{2} x_{4}+21.5 x_{3} x_{4}$

$\mathrm{DI}=82.66+5.75 \mathrm{x}_{1}-15.16 \mathrm{x}_{2}-4.83 \mathrm{x}_{3}+6.41 \mathrm{x}_{4}-3.95 \mathrm{x}_{1}^{2}-9.33 \mathrm{x}_{2}^{2}-2.08 \mathrm{x}_{3}^{2}+1.04 \mathrm{x}_{4}^{2}-2.5 \mathrm{x}_{1} \mathrm{x}_{2}-0.25 \mathrm{x}_{1} \mathrm{x}_{3}$

$-3.75 x_{1} x_{4}-5.0 x_{2} x_{3}+5.0 x_{2} x_{4}+3.75 x_{3} x_{4}$

\section{Wheat straw}

Initial BD $\left(\mathrm{kg} / \mathrm{m}^{3}\right)=598.33+5.58 \mathrm{x}_{1}-123.16 \mathrm{x}_{2}+20.25 \mathrm{x}_{3}+41.66 \mathrm{x}_{4}-29.45 \mathrm{x}_{1}{ }^{2}-51.83 \mathrm{x}_{2}{ }^{2}-13.45 \mathrm{x}_{3}{ }^{2}$

$-15.08 \mathrm{x}_{4}{ }^{2}-32.0 \mathrm{x}_{1} \mathrm{x}_{2}-0.25 \mathrm{x}_{1} \mathrm{x}_{3}-2.5 \mathrm{x}_{1} \mathrm{x}_{4}-12.75 \mathrm{x}_{2} \mathrm{x}_{3}-38.75 \mathrm{x}_{2} \mathrm{x}_{4}-0.75 \mathrm{x}_{3} \mathrm{x}_{4} \quad\left(\mathrm{r}^{2}=0.94\right)$

Final BD $\left(\mathrm{kg} / \mathrm{m}^{3}\right)=588.33+12.16 \mathrm{x}_{1}-118.5 \mathrm{x}_{2}+20.41 \mathrm{x}_{3}+35.75 \mathrm{x}_{4}-27.75 \mathrm{x}_{1}^{2}-61.5 \mathrm{x}_{2}^{2}-7.315 \mathrm{x}_{3}^{2}$

$-25.875 x_{4}^{2}-28.5 x_{1} x_{2}-2.5 x_{1} x_{3}-2.0 x_{1} x_{4}-14.75 x_{2} x_{3}-17.25 x_{2} x_{4}+1.5 x_{3} x_{4}$

$\left(r^{2}=0.96\right)$

$\mathrm{MC}(\%)=10.2-0.075 \mathrm{x}_{1}+1.86 \mathrm{x}_{2}-0.11 \mathrm{x}_{3}-0.14 \mathrm{x}_{4}+0.16 \mathrm{x}_{1}^{2}-0.025 \mathrm{x}_{2}^{2}-0.125 \mathrm{x}_{3}{ }^{2}+0.1875 \mathrm{x}_{4}^{2}-0.275 \mathrm{x}_{1} \mathrm{x}_{2}$

$-0.175 x_{1} x_{3}-0.025 x_{1} x_{4}-0.275 x_{2} x_{3}+0.45 x_{2} x_{4}$

$\mathrm{SDI}=327.66+50.16 \mathrm{x}_{1}-50.5 \mathrm{x}_{2}+13.75 \mathrm{x}_{3}+29.41 \mathrm{x}_{4} 32.5 \mathrm{x}_{1}^{2}-82.5 \mathrm{x}_{2}^{2}+9.87 \mathrm{x}_{3}^{2}-7.37 \mathrm{x}_{4}^{2}-17.25 \mathrm{x}_{1} \mathrm{x}_{2}$

$+10.75 \mathrm{x}_{1} \mathrm{x}_{3}+71.5 \mathrm{x}_{1} \mathrm{x}_{4}+24.25 .25 \mathrm{x}_{2} \mathrm{x}_{3}-0.5 \mathrm{x}_{2} \mathrm{x}_{4}+16.25 \mathrm{x}_{3} \mathrm{x}_{4}$ $\left(r^{2}=0.81\right) \ldots(20)$

$\mathrm{DI}=90.66+8.83 \mathrm{x}_{1}-8.08 \mathrm{x}_{2}+0.5 \mathrm{x}_{3}+2.41 \mathrm{x}_{4}-6.45 \mathrm{x}_{1}{ }^{2}-10.08 \mathrm{x}_{2}{ }^{2}+0.79 \mathrm{x}_{3}{ }^{2}-0.33 \mathrm{x}_{4}{ }^{2}+2.5 \mathrm{x}_{1} \mathrm{x}_{2}+1.5 \mathrm{x}_{1} \mathrm{x}_{3}$

$+7.5 x_{1} x_{4}+3.5 x_{2} x_{3}+5.75 x_{2} x_{4}+3.5 x_{3} x_{4} \quad\left(r^{2}=0.81\right) \quad \ldots(21)$

The high correlation coefficient values observed for the response surface models developed indicates that the process variables have adequately the briquette process of all the agricultural straws.

\section{Conclusions}

The various independent variables (moisture content, particle size distribution, densification temperature and pressure) are the underlined determining factors upon which the dependent quality parameters (density, durability and dimensional stability) rely upon. Proper and optimal 
combination of the independent variables is needed to manufacture biomass briquette with good quality. The right amount of moisture develops self-bonding properties in lignocellulosic materials like biomass. Canola straw produced briquette with better density, durability rating, and dimensional stability as compared to the other three biomass feedstocks. There is no fixed generic material and process variables for the densification of biomass feedstock due to their different chemical compositions and the interaction of the variables such as initial moisture and particle size distribution of the feedstock and briquetting temperature. Good quality briquettes can be produced with initial moisture contents of 9 to $12 \%$ (w.b.); however, the optimum moisture content for this experiment is $9 \%$ (w.b.). Durability rating is dependent on local melting (which depends on temperature) of some constituent of biomass feedstocks during densification process at satisfactory and required moisture content. At high temperature $\left(130^{\circ} \mathrm{C}\right)$ and low moisture (9-12\%), compacts with high durability rating were produced. At high pressure (12.5 $\mathrm{MPa}$ ) and low moisture (9-12\%), compact with high density were obtained. ANOVA demonstrated that temperature has positive correlation with durability rating and no significant effect on the density, while pressure is positively correlated with the compact density. Regressions developed for barely, wheat, oat and wheat straw briquette properties like initial bulk density, bulk density after two weeks of storage, moisture content, size distribution index and durability index has described the adequately with high correlation coefficient values. The data we have developed is further going to be analyzed by drawing the response surface plots and optimization using response surface methodology and genetic algorithm.

\section{Acknowledgements}

The authors are indebted to Cellulosic Biofuel Network (CBN) of Agriculture and Agri-Food Canada.

\section{References}

Adapa P., L. Tabil, and G. J. Schoenau. 2009b. Compaction characteristics of barley, canola, oat and wheat straw. Biosystems Engineering, 104, 335-344.

Adapa P., L. Tabil, and G. Schoenau. 2009a. Compression characteristics of selected ground agricultural biomass. Agricultural Engineering International: the CIGR Ejournal. Manuscript 1347. Vol. XI.

Adapa, P. K., G. J. Schoenau, L. G. Tabil, S. Sokhansanj, and B. Crerar. 2003. Pelleting of Fractionated Alfalfa Products. ASAE Annual International Meeting, Las Vegas, Nevada, July 27-30.

Al-Widyan, M. I., H. F. Al-Jalil, M. M. Abu-Zreig, and N. H. Abu-Hamdeh. 2002. Physical durability and stability of olive cake briquettes. Canadian Biosystems Engineering, 44, 3.41-3.45.

Arias, B., C. Pedida, J. Fermoso, M. G. Plaza, F. Rubiera, and J. J. Pis. 2008. Influence of Torrefaction on the Grindability and Reactivity of Woody Biomass. Fuel Processing Technology, 89, 169-175.

ASABE 2006. ASAE S358.2 - Moisture measurement - forages. In ASABE standards, pp. 608. American Society of Agricultural and Biological Engineers, St. Joseph, MI. 
ASABE 2007, ASAE S269.4 DEC1991 (R2007). Cubes, pellets and crumbles-definitions and methods for determining density, durability and moisture content. in ASABE standards, pp. 624-625. American Society of Agricultural and Biological Engineers, St. Joseph, MI.

Bilanski, W. K. and V. A. Graham.1984. A Viscoelastic Model for Forage Wafering. Transactions of the CSME, Canadian Society for Mechanical Engineers, 8(2), 70-76.

Briggs, J. L., D. E. Maier, B. A. Watkins, and K. C. Behnke. 1999. Effects of Ingredients and Processing Parameters on Pellet Quality. Poultry Science, 78, 1464-1471.

Briquetting manual (2007). Department of Agriculture and Bioresource Engineering, University of Saskatchewan, Saskatoon, Canada.

Colley, Z., O. O. Fasina, D. Bransby, and Y. Y. Lee. 2006. Moisture effect on the physical characteristics of switchgrass pellets. American Society of Agricultural and Biological Engineers, 49(6): 1845-1851.

Frazier, P. H., A. Crawshaw, N. W. R. Daniels, and P.W. R. Eggitt. 1983. Optimization of process variables in extrusion cooking of soya. In: Extrusion Cooking Technology. R. Jowitt (Ed.) Elsevier Applied Science Publishers, London and New York: 1-26.

Ghebre-Sellassie, I. 1989. Mechanism of pellet formation and growth. Pharmaceutical Pelletization Technology, Drugs and the pharmaceutical sciences, volume 37,123-130. Marcel Dekke, Inc., New York and Basel.

Granada, E., L. M. López-González, J. L. Míguez and J. Moran. 2002. Fuel lignocellulosic briquettes, die design and products study. Renewable Energy 27, 561-573.

Grover P. D. and S. K. Mishra. 1996. Biomass briquetting: technology and practices. Regional wood energy development program in Asia. GCP/RAS/154/NET, field document no. 46. Bangkok, Thailand: Food and Agriculture Organization of the United Nations.

Hoekman, S. K. 2009. Biofuels in the U.S. Challenges and opportunities. Renewable Energy 34, 14-22

Kaliyan, N. and R. V Morey. 2009. Factors affecting strength and durability of densified biomass products. Biomass and Bioenergy 33, 337-359

Kaliyan, N. and R.V. Morey, 2006, Densification Characteristics of Corn Stover and Switchgrass. Presented at the ASABE Annual International Meeting, July 9-12, 2006, Portland, OR, ASABE Paper No. 066174, ASAE, 2950 Niles Road, St. Joseph, MI 49085-9659, USA..

Kaliyan, N. and R. Morey, 2010. Natural binders and solid bridge type binding mechanisms in briquettes made from corn stover and switchgrass. Bioresource Technology, 101, 1082-1090

Khuri, A. Z. and J. A. Cornell, 1987. Response Surface Designs and Analysis. New York: Marcel Dekker, 149, 1987. 
Li, Y. and H. Liu. 2000. High Pressure Densification of Wood Residues to Form an Upgraded Fuel. Biomass and Bioenergy, 19, 177-186.

Mani, S., L. G. Tabil, S. and S. Sokhansanj. 2006b. Effects of compressive force, particle size and moisture content on mechanical properties of biomass pellets from grasses. Biomass and Bioenergy, 97, 1420-1426.

Mani, S., L. G. Tabil, and S. Sokhansanj. 2003. An overview of compaction of biomass grinds. Powder Handling \& Process, 15(3), 160-168.

Mani, S., L. G.Tabil, and S. Sokhansanj. 2004a. Grinding performance and physical properties of wheat and barley straws, corn stover and switchgrass. Biomass and Bioenergy 27, $339-352$

Mani, S., L. G.Tabil, and S. Sokhansanj. 2004b. Compaction of corn stover. ASAE Paper No 041160, presentation at the 2004 ASAE/CSAE Annual International Meeting.

Mani, S., L. G. Tabil, and S. Sokhansanj, 2006a. Specific Energy Requirement for Compacting Corn Stover. Bioresource Technology, 97, 1420-1426.

Ndiema, C. K. W., P. N. Manga, and C. R. Ruttoh. 2002. Influence of Die Pressure on Relaxation Characteristics of Briquetted Biomass. Energy Conversion and Management, 43, 2157-2161.

Obernberger, I. and G. Thek. 2004. Physical characterisation and chemical composition of densified biomass fuels with regard to their combustion behaviour. Biomass and Bioenergy, 27:653-69. Saskatchewan Ministry of Agriculture. 2009. http://www.agriculture.gov.sk.ca/Stastistics (2009/10/12/).

Shankar, T. J. and S. Bandyopadhyay. 2004. Optimization of extrusion process variables using a genetic algorithm.Trans IChemE, Part C, Food Bioproducts Processing, 82(C2), 143-150.

Shankar, T. J. and S. Bandyopadhyay. 2005. Process Variables during Single Screw Extrusion of Fish and Rice Flour Blends. Journal of Food Processing and Preservation, 29, 151164.

Shankar, T. J., S. Sokhansanj, S. Bandyopadhyay and A. S. Bawa. 2010. A Case Study on Optimization of Biomass Flow During Single-Screw Extrusion Cooking Using Genetic Algorithm (GA) and Response Surface Method (RSM). Food and Bioprocess Technology, 2 (2), 109-123.

Sokhansanj S., S. Mani, M. Stumborg, R. Samson, and J. Fenton, 2006. Production and distribution of cereal straw on the Canadian prairies. Canadian Biosystems Engineering, 48, 3.39-3.46.

Sokhansanj S., S. Mani, X. Bi, P. Zaini, L. G. Tabil., 2005. Binderless pelletization of biomass, ASAE Paper No. 056061, presentation at the 2005 ASAE Annual International Meeting, Tampa Convention Centre, Tampa, Florida July 17-20. 
Tabil, L.G. 1996. Binding and pelleting characteristics of alfalfa. Unpublished Ph.D. thesis. Saskatoon, Saskatchewan, Department of Agricultural and Bioresource Engineering, University of Saskatchewan.

Tabil, L. G. and S. Sokhansanj, 1996, Compression and Compaction Behavior of Alfalfa Grind: Part 2: Compaction Behavior. Powder Handling \& Processing, 8(2), 1996.

Thomas, M., T van Vliet, and A. F. B. van der Poel.1998, Physical Quality of Pelleted animal Feed 3. Contribution of Feedstuff Components. Animal Feed Science Technology, 70, 59-78, 1998.

Tumuluru, J. S., L. Tabil, A. Opoku, M. R. Mosqueda, and O. Fadeyi. 2010. Effect of Process Variables on the Quality Characteristics of Pelleted Wheat Distiller's Dried Grains with Soluble. Biosystems Engineering, 105(4), 466-475.

United Nations (UN), 1998. Kyoto Protocol to the United Nations Framework convention on Climate Change,

van Dam, J. E. G., M. J. A. van den Oever, W. Teunissen, E. R. P. Keijsers, and A. G. Peralta. 2004. Process for Production of High Density/High Performance Binderless Boards from Whole Coconut Husk-Part 1: Lignin as Intrinsic Thermosetting Binder Resin. Industrial Crops and Products, 19(3), 207-216.

Wood, J. F. 1987. The Functional Properties of Feed Raw Materials and the Effect on the Production and Quality of Feed Pellets. Animal Feed Science and Technology, 18, 117. 